\title{
Exploring the Value Dimensions and Their Impact on Customer Loyalty in Indian Banking Services
}

\author{
Debajani Sahoo, Achyut Telang \\ Department of Marketing and Strategy, IBS Hyderabad (Constituent of IFHE Deemed University), Hyderabad, India \\ Email: debajanis1@yahoo.co.in, achyutktelang@ibsindia.org
}

How to cite this paper: Sahoo, D. and Telang, A. (2019) Exploring the Value Dimensions and their Impact on Customer Loyalty in Indian Banking Services. Theoretical Economics Letters, 9, 1938-1954. https://doi.org/10.4236/tel.2019.96123

Received: June 17, 2019

Accepted: August 19, 2019

Published: August 22, 2019

Copyright $\odot 2019$ by author(s) and Scientific Research Publishing Inc. This work is licensed under the Creative Commons Attribution International License (CC BY 4.0).

http://creativecommons.org/licenses/by/4.0/

\begin{abstract}
The purpose of the present study is to investigate the impact of the multiple dimensions of perceived value on customer experience metrics and loyalty. It also advances the concept of consumer value in the service industry, through modeling and measurement in service set up like banking. A web-based survey among $345 \mathrm{~m}$-banking users was employed to gather data regarding the proposed set of constructs. A Structural Equation Modelling (SEM) technique was used to analyze the conceptual model and test the proposed set of hypotheses. The study results supported the fact that banking perceived value consists of five dimensions, such as Behavioral price, Monetary price, Emotional response, Quality, Reputation. The total configuration of these dimensions influences customer loyalty via the development of evaluation of customers towards banking services.
\end{abstract}

\section{Keywords}

Service Perceived Value, Customer Loyalty, Customer Service Experience, Banking Service, Indian Economy

\section{Introduction}

Customer perceived value over the years has gained a lot of importance from both academic community and practitioners due to its significant role in assessing consumer buying behavior [1] and for attaining a sustainable edge in the competitive market [2]. In fact, perceived value has become one of the critical business issues from the 1990s and continues to be one of the focal areas of research. Even though it has become a key factor of strategic management [3] and consumer behavior, due to the scattered and non-conclusive patterns of research 
in this area, there lies a wide gap in overall general consensus about the construct [4]. This has made value as one of the most misused concepts of management literature [5], so understanding the importance of perceived value in different service context is highly essential.

With the advent of the service dominant logic [6] the focus has shifted towards services research and thus the concept of perceived value has been extended to the field of services marketing. According to Lovelock [7] enhancement of perceived service value can be achieved through the addition of benefits or through reduction of outlays associated with the purchase and use of a service. Customer service experience is the reflection of the perceived value of service and further, leads to other outcomes such as repurchase intention [8]. Previous research suggests that engendering superior customer experience is one of the ways to achieve successful marketing outcomes and firm's success. Even though previous studies explained and tested the individual impact of perceived value, customer service experience on business success like profit and customer loyalty [8], yet there are not many studies that conceptualize all the three construct relationship in service context like banking.

Based on the arguments mentioned above, the present study tries to mitigate the gap by formulating a few objectives. The purpose of the present study is to advance the concept of consumer value in service industry, through modeling and measurement in different service contexts as well as to investigate the impact of the multiple dimensions of perceived value on customer experience metrics and loyalty. Hence this study explores the service value dimensions in service set ups like banking. Subsequently, it investigates the differential impact of these dimensions on customer experience and customer loyalty. The objectives of this study are thus two-fold. First, to explore the underlying dimensions of service value in the service setups of Indian retail banking services followed by investigation of the impact of the service value dimensions on customer experience and customer loyalty in service setups.

The rest of the paper is as follows: First, the literature on customer perceived value in services, the multidimensional and contextual nature of service value, the impact of service value dimensions on customer experience, loyalty and the relevance of service value in the service setups of retail banking and business school education services are all reviewed. Next, the article talks about the research methodology used in the paper and the survey instrument used in data collection. Finally, the results of the analysis followed by a discussion of the findings as well as highlighting further research possibilities are presented.

\section{Literature Review and Hypothesis Development}

\subsection{Customer Perceived Value in Services}

Perceived value has been defined as "based on perceptions of what is received and what is given" [9]. Zeithaml [9] explained four meanings of value such as: value is low price, value is whatever one wants in a product, value is that con- 
sumer receives for the price paid, and value is what the consumer gets for what they give. Although there has been a lot of previous literature in marketing on conceptualizing and measuring customer perceived value, most of these have been done in the context of products. Like in products, understanding the customer perceptions of value they derive from availing a service is considered crucial. However, till date, not much work has been done to operationalize and measure value in the context of services [10] unlike in products where the concept of perceived value has been measured through existing, established scales. Petrick [10] developed the SERV-PERVAL scale to measure perceived value by including dimensions such as emotional response, reputation, monetary price and behavioral price and quality in a tourism service context. They have been defined in following ways:

The descriptive judgement regarding the pleasure that a product or service delivered to a consumer is called as Emotional response. The price of a service encoded by the consumer is called monetary price. The non-monetary price such as time and effort used to search for the service is called as Behavioral Price [9]. The prestige or status of a product or service, as perceived by the purchaser, based on the image of the supplier is called as Reputation. A consumer's judgement about a product or service's overall excellence or superiority is called as Quality [9]. According to Ganesh, Aronold \& Reynolds [11] consumer value perceptions and preferences vary across contexts. MacDougall \& Levesque [12] also studied the differential impacts of service value on customer behavioral intentions in four different service setups or contexts.

Just like all other financial services, the banking industry is rapidly changing with new technologies being introduced. Growing competition as well as more demanding customers and the changing vulnerable climate due to economic uncertainties also present an unprecedented set of challenges [6]. As banking is totally a customer-oriented services industry, the customers are the central point of all decisions and thus customer service has to be a clearly distinguishing factor. Most banks face the challenges of lowering costs and increasing efficiency, besides improving service quality and subsequently customer satisfaction [13]. This makes it necessary to have the loyal customers or the customers to be retained for a long term, which is more economical than attracting new customers [14]. So, the managers of retail banks are concerned in increasing their satisfied customer base together with making them loyal and attracting new customers. In order to do so, managers need to concentrate on the antecedents of customer loyalty and service value in its multidimensional nature is one of the most comprehensive and exhaustive measures of that.

\subsection{Customer Perceived Value and Service Experience}

Customer Experience (CE) is defined as the cognitive acknowledgment or perception that follows from stimulated motivation of a customer who observes or participates in an event. These acknowledgment or perception consequently 
augments the value of products and services. Marketers use both intangible services accompanied with tangible products to create memorable events for customers. CE is crucial as it creates the psychological perception in the hearts of customers, provides a memorable experience for the customer, and influences subsequent usage behaviors in a great way. Enlightening CE can help marketers to identify niche markets than does maintaining competitive prices or superior product functions and features. The perceived value of a product or service can be an antecedent of Word of mouth [15] and lead to a better service experience to the consumer. In different service context consumer got different service experience based on the particular perceived value.

\subsection{Impact of Customer Perceived Value on Customer Service Experience and Loyalty}

Current study uses Stimulus-Organism and Response S-O-R framework [16] as a basis to formulate the conceptual model. The S-O-R framework states that stimuli (S) are antecedents that affect consumers' emotional and cognitive states of an organism $(\mathrm{O})$, which in turn result in response $(\mathrm{R})$, such as consumers' behavior related outcomes. The stimuli are represented by a set of attributes that affect consumer perception. These attributes are considered to be the basis for the development of consumer behavior related outcomes, i.e., these attributes work as cues or signals which influence the observing customers' cognition and affection and will lead them to act consciously or subconsciously towards a given action. Marketing literature further classifies these stimuli as "informational" versus "transformational" [17]; "utilitarian" versus "value-expressive" [18], and "hard-sell" versus "soft-sell" [19]. While the former stimuli can be classified under functional stimuli, the latter are considered as experiential stimuli. The organism (i.e. cognitive state) works as a process of internal intervention between the stimuli and the response of the consumer. In this process, the consumer transforms the stimuli into meaningful information while developing perceptions of such information. Perception(s) can cause a change in individuals' affective and cognitive states, leading to response (R). The response is the reaction (behavioral) of the consumer in (intending to) undertaking specific course(s) of $\operatorname{action}(s)$.

Service brand experience is an emerging concept in services marketing literature that refers to the customer encounter with a service brand which creates a cognitive, emotional, and behavioral response in consumers' memory. It refers to the broader set of customer-brand interactions and encompasses the total experience with the service brand before, during, and after the service purchase. Thus, service brand experience is a multidimensional construct that is the sum total of sensations, cognitions, feelings, and behavioral responses evoked by customer interaction with the service brand, involving an integrated interaction with the services cape, service employees and their interactions, communications, service delivery process, and environments.

Service experiences vary in strength and intensity; such as, some brand expe- 
riences are stronger or more intense than others; some are more positive and some experiences may even be negative. Moreover, some experience occurs spontaneously without much reflection and are short-lived; others occur more deliberately and last longer. Over time, these long-lasting service experiences, stored in consumer memory, should affect consumer satisfaction and loyalty [20]. As compared to customer delight, service experiences don't happen only after consumption; they happen whenever there is a direct or indirect interaction with the brand. Thus, we conceptualize service experience as subjective, internal consumer responses (sensations, feelings, and cognitions) and behavioral responses. Thus, service managers are becoming increasingly aware of the quality and value of services that are required in order to create a memorable experience for customers and that leads to behavioral intentions [21]. Providing persuasive $\mathrm{CE}$ can set a firm ahead of its competitors, and superior CE has been acknowledged as key to gaining customer loyalty.

From a marketing perspective, customers are the reason for the firm's existence. There exists plenty of evidence in marketing literature that suggests that perceived value is an antecedent to both customer satisfaction and customer loyalty [22]. According to Tam [23] the degree by which customers' perception of the quality of service exceeds the perceived costs of obtaining the service; the higher is their perceptions of the value of the service, which leads to greater satisfaction. There are also other studies which have shown that perceived value exhibits a significant impact on customer satisfaction [24] [25] [26] [27]. Roig, Garc1'a \& Tena [28] also found that the perceived value of a service has a direct positive effect on the loyalty of the consumers.

Berkman, Lindquist \& Sirgy [29] define customer loyalty as "the feeling of attachment, affection, or commitment to a service provider". Customer loyalty basically is the consumer bias and commitment towards a particular product or a service provider [30]. Andreassen \& Lindestad [31], as well as MacDougall \& Levesque [13], argue that the effect of value on behavioral intents like loyalty is mediated by customer satisfaction. Studies have been conducted to show the direct impact of perceived value on customer loyalty too [1]. Practioners have confirmed customer experience (CE) as one of the most promising approaches for consumer industries. Customer experience (CE) shows the customer's journey through all communications with the firm-pre-consumption, consumption, and post-consumption. But there are comparatively lesser studies which have investigated the effect of customer experience as a mediator between perceived value and behavioral intention.

\subsection{Summary of Literature Review}

Customer Experience influences subsequent usage behaviors and it can help marketers to identify niche markets. The perceived value of a product or service can lead to a better service experience for the consumer which is different in various service contexts based on the particular perceived value. Long-lasting 
service experiences, affect consumer satisfaction and loyalty and they happen whenever there is a direct or indirect interaction with the brand. Thus, service managers are becoming increasingly aware of the quality and value of services that are required in order to create a memorable experience for customers and that leads to behavioral intentions. Providing persuasive CE can set a firm ahead of its competitors, and is a key to gaining customer loyalty. The degree by which customers' perception of the quality of service exceeds the perceived costs of obtaining the service; the higher is their perceptions of the value of the service, which leads to greater satisfaction as well as loyalty. Practioners have confirmed customer experience (CE) as one of the most promising approaches for consumer industries but there are comparatively lesser studies which have investigated the effect of customer experience as a mediator between perceived value and behavioral intention.

\section{Hypotheses of the Study and Model}

Hypothesis 1 (H1): Customer Perceived value has a positive relationship with service experience in banking service context.

Hypothesis 2 (H2): Customer service experience across service sector has a positive relationship with customer loyalty.

Hypothesis 3 (H3): Customer service experience in service sector mediates the relationship between the customer perceived value and customer loyalty.

Based on the above, a model is proposed and Figure 1 shows the hypothesized model of perceived value on customer loyalty via customer service experience. In this model, the customer perceived value was conceptualized as a second order construct (consisting of five first order dimensions) and all other constructs (e.g. customer service experience and customer loyalty) were conceptualized as first order dimensions. The second order conceptualization of customer perceived value was formulated based on assumption that it is the "total configuration" of the dimensions that determine the overall evaluation of the customer value in a service context [1]. We have considered customer perceived value as a higher order factor consisting of five lower order factors, namely behavioral price, monetary price, emotional response, quality, and reputation. Based on the S-O- $\mathrm{R}$ framework, it is assumed that the total configuration of these dimensions influence

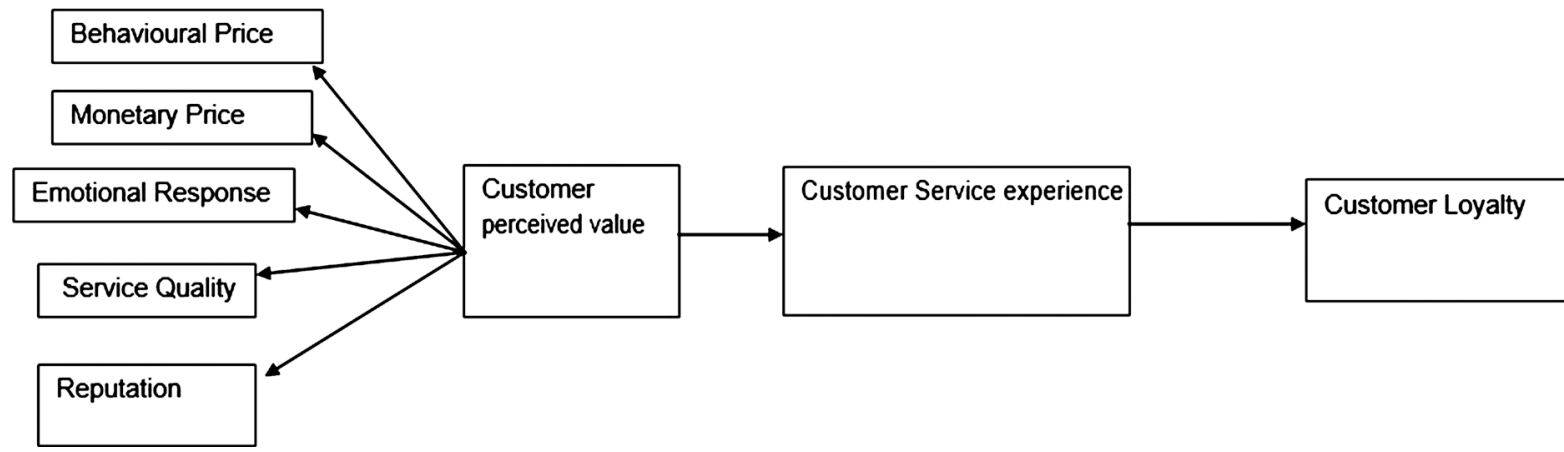

Figure 1. Proposed conceptual model. 
customer evaluation and experience and thus develops customer loyalty behaviors.

\section{Research Methodology}

The study was conducted both in public and private banking customers. One reason for choosing this setting was that banking services involve different types of delivery pattern like mobile banking, online banking, branch banking, ATM that includes technology-based self services. They also are used as standard offering by providing bill payment service; multiple channels offered ranging from full service to self service option. Another reason is that an emerging economy like India, different government schemes like Jan Dhan Yojana, subsidy, etc. induce the customers for a banking transaction.

Self administered questionnaires were used to collect data for the study from one of the emerging economies, India. For the retail banking setup, the respondents were Indian nationals who held at least one bank account for not less than 6 months. The respondents were first asked to mention the name of the bank where they carried out their maximum number of transactions (in case they held accounts in multiple banks). The purpose was explained and confidentiality of the customer information was guaranteed. Simple random sampling method was followed to reduce the sampling error. Mall intercept survey method was used for the data collection. The respondents were approached at the shopping mall, when they were in a relaxed mood. As an incentive towards active participation, all participants were promised a free retail store coupon after the completion of the survey. In the survey, respondents were instructed to answer questions based on their value perception and experience followed by their loyalty towards the bank. In total 420 usable questionnaires were obtained with a response rate of about $83 \%$. The convenience sample included 62 percent of male and 38 percent female in the age group of 30 to 50 and above. All the respondents were asked to state their level of agreement against the series of statements pertaining to banking services. Table 1 shows the detailed demographic details of the respondents.

\section{Measures}

In the survey, all hypothesized constructs were measured through multi-item scales to capture the meaning. All these measures were adopted from prior literature and modified to match the banking context. The scale items are then confirmed the content validity. In total, the final survey questionnaire consists of 40 items (refer Appendix 1).

In the survey questionnaire, items were divided into four sections. The first section captures respondents' perceived value from banking context. In order to measure banking perceived value, the researcher adapted the scale from Petrick [10]. According to Petrick [10], the higher order perceived value construct composed of five dimensions such as behavioral price (5 items), Moneytary price (6 items), Emotional Response (5 items), Quality (4 items) and Reputation (5 items). All the perceived value items were measured along a seven-point Likert scale 
Table 1. Demographic details.

\begin{tabular}{|c|c|}
\hline Items and Category & Frequency \\
\hline \multicolumn{2}{|l|}{ Gender: } \\
\hline Male & $260(62 \%)$ \\
\hline Female & $160(38 \%)$ \\
\hline \multicolumn{2}{|l|}{ Age (in years) } \\
\hline Below 30 years & $105(25 \%)$ \\
\hline $31-39$ years & $151(36 \%)$ \\
\hline $40-49$ years & $101(24 \%)$ \\
\hline 50 years and above & $63(15 \%)$ \\
\hline \multicolumn{2}{|c|}{ Annual household income (in rupees) } \\
\hline Less than 6 lakh & $134(32 \%)$ \\
\hline 6 lakh to 12 lakh & $181(43 \%)$ \\
\hline 12 lakh to 16 lakh & $76(18 \%)$ \\
\hline More than 16 lakh & $29(7 \%)$ \\
\hline \multicolumn{2}{|l|}{ Household size (in number) } \\
\hline Less than 3 & $71(17 \%)$ \\
\hline 4 to 6 & $227(54 \%)$ \\
\hline 6 and above & $122(29 \%)$ \\
\hline \multicolumn{2}{|l|}{ Occupation: } \\
\hline Student & $67(16 \%)$ \\
\hline Employed in the public sector & $100(24 \%)$ \\
\hline Employed in the private sector & $147(35 \%)$ \\
\hline Self employed & $64(15 \%)$ \\
\hline Others & $42(10 \%)$ \\
\hline \multicolumn{2}{|l|}{ Types of bank } \\
\hline Private & $227(54 \%)$ \\
\hline Public & $193(46 \%)$ \\
\hline
\end{tabular}

("Strongly disagree" = 1 to "Strongly agree" = 7). The measurement of customer service experience towards banking service was adopted from Brakus et al. [32], consisting of four subdimensions such as sensory, affective, behavioral and intellectual. The 12 items of customer service experience were measured along a seven-point Likert scale ("Strongly disagree" = 1 to "Strongly agree" =7). The measurement of customer loyalty towards banking was adopted from Zeithaml et al. [33] consisting of three items. All the customer loyalty items were measured along a seven-point Likert scale ("Strongly disagree" = 1 to "Strongly agree" =7). Finally, the survey contained questions related to customer demographics such as age, gender, education, income, occupation, household size, bank types and so on. Table 2 contains details of the items used in the survey questionnaire. 
Table 2. Descriptive statistics, AVE and correlations for the hypothesized constructs.

\begin{tabular}{cccccccccc}
\hline Constructs & Mean & SD & 1 & 2 & 3 & 4 & 5 & 6 & 7 \\
\hline Service quality (1) & 5.55 & 1.21 & 0.83 & & & & & & \\
Emotional response (2) & 6.01 & 0.91 & $0.51^{\star}$ & 0.79 & & & & & \\
Monetary price (3) & 5.90 & 1.12 & $0.41^{\star}$ & $0.39^{*}$ & 0.76 & & & & \\
Behavioral price (4) & 5.47 & 0.92 & 0.29 & $0.33^{*}$ & 0.42 & 0.79 & & & \\
Reputation (5) & 4.98 & 0.98 & 0.21 & 0.34 & 0.27 & $0.39^{* *}$ & 0.74 & & \\
Customer service experience (6) & 5.02 & 0.94 & 0.35 & 0.27 & $0.43^{*}$ & 0.33 & $0.28^{\star *}$ & 0.82 & \\
Customer loyalty (7) & 5.78 & 1.02 & 0.40 & 0.43 & 0.28 & $0.27^{*}$ & 0.31 & 0.33 & 0.84 \\
\hline
\end{tabular}

Notes: $\mathrm{N}=420 ;{ }^{*} p<0.05,{ }^{* *} p<0.01$. Level, diagonal elements show Average Variance Extracted (AVE).

\section{Data Analysis and Results}

The proposed set of hypotheses was tested by following two-step procedures of Anderson and Gerbing [34]. First, prior to the testing of hypotheses, we have carried out measurement model testing through confirmatory factor analysis (CFA) to confirm the psychometric properties of the constructs. After the measurement model confirmation, we have examined the structural model to examine the hypotheses. In this stage, the study also examined the mediating role of customers' banking service experience between customer perceived value and customer Loyalty. The following sub-sections detail these stages. A combination of SPSS 24 and AMOS 10.0 software packages was used to carry out all the data analyses.

\subsection{Construct Validation: Measurement Model Analysis}

Measurement model testing was performed using AMOS (version 10.0) to examine the presence of construct validity and reliability, including convergent and discriminant validity. Convergent validity of the scale dimensions explains the extent to which items measuring their corresponding construct are correlated [34]. The convergent validity of the constructs could be satisfactory if factor loadings and average variance extracted (AVE) are above the threshold of 0.5 [35]. From the analysis, it was found that all standardized loadings on the latent constructs were significant $(\mathrm{p}<0.001$, ranges from 0.615 to 0.893$)$, supporting convergent validity of all scale dimensions. The examination of the measurement model showed a good fit $\mathrm{X}^{2}(328)=539.63(\mathrm{P}<0.001),\left(\mathrm{X}^{2} / \mathrm{df}=2.26\right.$; GFI $=$ $0.970 ; \mathrm{AGFI}=0.951 ; \mathrm{NFI}=0.979 ; \mathrm{CFI}=0.947 ; \mathrm{RMSEA}=0.049)$. Further, for all the constructs AVE values were greater than the preferred cut-off, confirming convergent validity. Discriminant validity captures the extent to which the constructs proposed in the study are unique and distinct from each other, this can be examined through the comparison of AVE estimates to squared inter-construct correlations [36]. Discriminant validity should be achieved if the squared inter-construct correlations should be smaller than the AVEs [37]. Table 3 indicates that in all the cases the square roots of AVE values were greater than their 
Table 3. Confirmatory factor analysis.

\begin{tabular}{ccccc}
\hline \multirow{2}{*}{ Constructs/Items } & \multicolumn{2}{c}{ Banking Sector } & \multicolumn{2}{c}{ Education Sector } \\
\cline { 2 - 5 } & Loadings & t-value & Loadings & t-value \\
\hline Service quality (1) & 0.74 & 13.2 & 0.76 & 17.4 \\
Emotional response (2) & 0.67 & 12.2 & 0.72 & 17.7 \\
Monetary price (3) & 0.86 & 13.0 & 0.74 & 18.5 \\
Behavioral price (4) & 0.75 & 17.7 & 0.68 & 17.0 \\
Reputation (5) & 0.81 & 18.4 & 0.85 & 18.8 \\
Service experience (6) & 0.77 & 16.6 & 0.70 & 13.0 \\
Loyalty (7) & 0.70 & 13.3 & 0.79 & 18.4 \\
& Goodness of fit statistics & & \\
$x^{2}$ & 216.2 & & & \\
d.f. & 120 & & \\
NFI & 0.98 & & \\
NNFI & 0.99 & & \\
CFI & 0.99 & & \\
RMSR & 0.04 & & \\
RMSEA & 0.047 - 0.057 & & \\
(90\% CI) & & & \\
\hline
\end{tabular}

Based on one-tailed tests: for $\mathrm{t}$-values greater than $1.65, \mathrm{p}<0.05$; for $\mathrm{t}$-values greater than $2.33, \mathrm{p}<0.01$.

corresponding inter-construct correlations, confirming discriminant validity. In support with these findings, the composite reliability (CR) estimates of all hypothesized constructs were between 0.746 and 0.952 , suggesting adequate scale reliability [38]. All these findings support construct validity and reliability of the scale dimensions.

\subsection{Structural Model Analysis and Hypotheses Testing}

After confirming the psychometric properties of the scale dimensions, overall model fit was examined by conducting structural equation modelling (SEM). The considered model fit indices include: ratio of the chi-square to the degree of freedom $\left(\mathrm{X}^{2} / \mathrm{df}\right)$, Comparative Fit Index (CFI), Goodness of Fit Index (GFI), Adjusted Goodness of Fit Index (AGFI), Normed Fit Index (NFI), and Root Mean Square Error of Approximation (RMSEA). A model is considered to be good fit to the data when the values of CFI, NFI, and GFI are greater than 0.9, AGFI is greater than 0.8 , RMSEA is smaller than 0.08 , and $\mathrm{X}^{2} / \mathrm{df}$ is smaller than 5 [36] [38]. The examination of the model fit indices support the fact that the model fit very well to the data $\left(\mathrm{X}^{2} / \mathrm{df}=2.323\right.$; GFI $=0.982$; $\mathrm{AGFI}=0.961$; $\mathrm{NFI}=$ 0.969; CFI $=0.957$; RMSEA $=0.039$ ). Then, the examination of the hypotheses shows that the relationship between perceived value in banking on customers' service experience is significant (Hypothesis 1: $\beta=0.572, \mathrm{t}=10.617, \mathrm{p}<0.001$ ). 
This supports the fact that perceived value in banking positively influences customers' banking experience towards the same. The standardized path coefficient from customers' banking experience towards customer Loyalty also found to be significant (Hypothesis 2: $\beta=0.479, \mathrm{t}=6.65, \mathrm{p}<0.001$ ). This finding indicates that customers' banking experience towards the banking is a significant and direct predicator of customer loyalty. To examine the indirect relationship of banking perceived value on customer loyalty, we have used Baron and Kenny's (1986) procedure. The result shows the fact that the indirect effect of banking perceived value on customer loyalty has a significant effect (indirect effect $=$ $0.213, \mathrm{p}<0.001)$. Moreover, the result also supports the fact that there is a significant direct effect from banking perceived value on customer loyalty (direct effect: $0.015, \mathrm{p}<0.001)$. Thus, it supports the partial mediation of customer banking experience in between banking perceived value and customer loyalty (Hypothesis 3). In total, the study results supported the fact that banking perceived value consists of five dimensions, such as behavioural price, monetary price, Emotional response, Quality, Reputation. The total configuration of these dimensions influences customer loyalty via the development of evaluation of customers towards banking services (Figure 2).

\section{Discussion}

The service setups considered for the study are Indian retail banking service. The nature of the service setups is defined based on certain criteria (ease of evaluation, purchase importance, ease of switching, difference in service provider quality) just like McDougall and Levesque [12] defined four different services. While banking services is more of a corporate setup. It is easier to evaluate a banking service than other services. Both are important purchases, but ease of switching is more in banking. Also difference in quality between service providers is more pronounced in case of the banking service. The empirical phase of the research was focussed primarily on identifying the underlying factors that capture the multidimensionality of perceived service value in the setups. The findings support that perceived value of a banking setup consists of dimensions such as Service Quality, Emotional Response, Monetary Price, Behavioral Price

Behavioural Price

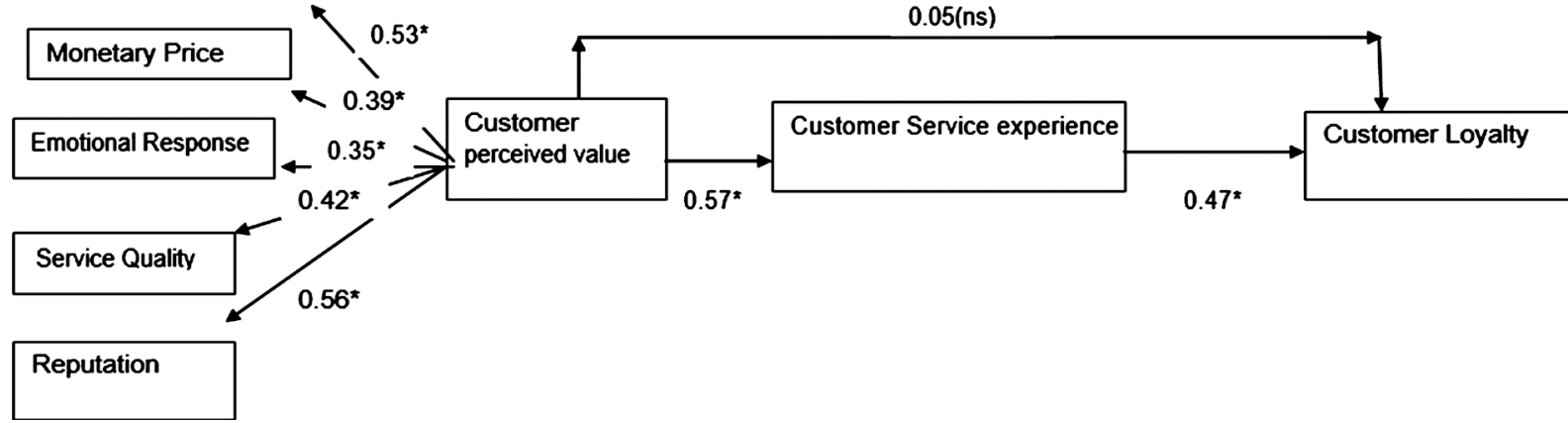

Figure 2. Estimated path coefficients. 
and Reputation that those have an active role for a better customer experience. In the subsequent phase the effect of these dimensions on customer experience and customer loyalty are investigated. Holbrook \& Corfman [39] have suggested that the perception of value is situational in nature and depends on the context within which the customers judge service value. Fernández, Bonillo \& Holbrook [4] also suggested that the concept of value is dynamic and contextual in nature. Also, the effect of value dimensions on customer loyalty showed quite contrasting results for the service setups.

The analytical results obtained herein are consistent with that of previous research and supported the linear relationship among the attitudinal and psychological construct like experience and loyalty in a banking service context. Furthermore, past studies that tested the S-O-R framework also holds well in this banking service context for a better loyalty between the organization and the customer. In Summary, this research found that perceived value dimensions have an impact on better customer evaluation. So Marketing Managers should focus on perceived value to have a better customer experience and loyalty.

\section{Conclusion}

Customer can face positive or negative and short-lived or long-lasting service experiences based on the value dimensions. Long-lasting brand experiences, stored in the customer's memory, affect customer loyalty and satisfaction [40]. This study can be a useful guide for managers of banking services for understanding the consumer psyche about service value perception as in determination of marketing strategies service value is now a better, broader and more crucial concept than any other concepts of consumer perceptions of service. It is the value (what you get versus what you spent) which matters most to today's consumers and hence this study will help the manager to understand how much value (importance) is to be given to the different value dimensions in order to increase customer satisfaction and loyalty. It will help the managers to properly evaluate and plan the emphasis to be given to the different value dimensions as well as compare themselves with the competitors. Of course, with convenience sampling used generalization of the results should be done with caution. However, in spite of limitations, this study significantly contributes to the literature of services marketing and service value in particular, by identifying the value dimensions in service setups and subsequently examining the impact of value dimensions on customer loyalty. This is important because of the fact that conceptualization and measurement of service value are still in a developing phase and thus this study contributes towards the development of service value concept. In future this study can be advanced by using multiple group analysis techniques by using moderator like bank types, prior experience, etc. as well as using different other types of service contexts like cellular communication service, airlines service, hospitality services. 


\section{Conflicts of Interest}

The authors declare no conflicts of interest regarding the publication of this paper.

\section{References}

[1] Parasuraman, A. and Grewal, D. (2000) The Impact of Technology on the Quality-Value-Loyalty Chain: A Research Agenda. Journal of the Academy of Marketing Science, 28, 168-174. https://doi.org/10.1177/0092070300281015

[2] Chen, Z. and Dubinsky, A.J. (2003) A Conceptual Model of Perceived Customer Value in E-Commerce: A Preliminary Investigation. Psychology \& Marketing, 20, 323-347. https://doi.org/10.1002/mar.10076

[3] Mizik, N. and Jacobson, R. (2003) Trading Off between Value Creation \& Value Appropriation: The Financial Implications of Shifts in Strategic Emphasis. Journal of Marketing, 67, 63-76. https://doi.org/10.1509/jmkg.67.1.63.18595

[4] Fernández, R.S., Bonillo, M.Á.I. and Holbrook, M.B. (2008) The Conceptualisation \& Measurement of Consumer Value in Services. International Journal of Market Research, 51, 93-113.

[5] Khalifa, A.S. (2004) Customer Value: A Review of Recent Literature and an Integrative Configuration. Management Decision, 42, 645-666. https://doi.org/10.1108/00251740410538497

[6] Vargo, S.L. and Lush, R.F. (2004) Evolving to a New Dominant Logic of Marketing. Journal of Marketing, 68, 1-17. https://doi.org/10.1509/jmkg.68.1.1.24036

[7] Lovelock, C. (2001) Services Marketing: People, Technology, Strategy. 4th Edition, Prentice Hall, Upper Saddle River.

[8] Kim, H. and Choi, B. (2013) The Influence of Customer Experience Quality on Customers' Behavioral Intentions. Services Marketing Quarterly, 34, 322-338. https://doi.org/10.1080/15332969.2013.827068

[9] Zeithaml, V.A. (1988) Consumer Perceptions of Price, Quality \& Value: A Means-End Model \& Synthesis of Evidence. Journal of Marketing, 52, 2-22. https://doi.org/10.1177/002224298805200302

[10] Petrick, J.F. (2002) Development of a Multi-Dimensional Scale for Measuring the Perceived Value of Services. Journal of Leisure Research, 34, 119-134. https://doi.org/10.1080/00222216.2002.11949965

[11] Ganesh, J., Arnold, M.J. and Reynolds, K.E. (2000) Understanding the Customer Base of Service Providers: An Examination of the Differences between Switchers \& Stayers. Journal of Marketing, 64, 65-87. https://doi.org/10.1509/jmkg.64.3.65.18028

[12] McDougall, G.H.G. and Levesque, T. (2000) Customer Satisfaction with Services: Putting Perceived Value into the Equation. Journal of Services Marketing, 14, 392-410. https://doi.org/10.1108/08876040010340937

[13] Chakravarty, S.W.R. (1996) How Moment of Truth Define Bank-Customer Relationship. Journal of Retail Banking Services, 18, 29-34.

[14] Reichheld, F.F. and Kenny, D. (1990) The Hidden Advantages of Customer Retention. Journal of Retail Banking, 12, 19-23.

[15] Mukerjee, K. (2018) The Impact of Brand Experience, Service Quality and Perceived Value on Word of Mouth of Retail Bank Customers: Investigating the Mediating Effect of Loyalty. Journal of Financial Services Marketing, 23, 12-24. https://doi.org/10.1057/s41264-018-0039-8 
[16] Mehrabian, A. and Russell, J.A. (1974) An Approach to Environmental Psychology. MIT Press, Cambridge.

[17] Rossiter, J.R. and Percy, L. (1987) Advertising and Promotion Management. McGraw-Hill Book Company, New York.

[18] Johar, J.S. and Sirgy, M.J. (1991) Value-Expressive versus Utilitarian Advertising Appeals: When and Why to Use Which Appeal. Journal of Advertising, 20, 23-33. https://doi.org/10.1080/00913367.1991.10673345

[19] Okazaki, S., Mueller, B. and Taylor, C.R. (2010) Measuring Soft-Sell versus Hard-Sell Advertising Appeals. Journal of Advertising, 39, 5-20. https://doi.org/10.2753/JOA0091-3367390201

[20] Calik, N. and Balta, N.F. (2006) Consumer Satisfaction and Loyalty Derived from the Perceived Quality of Individual Banking Services: A Field Study in Eskisehir from Turkey. Journal of Financial Services Marketing, 10, 135-149. https://doi.org/10.1057/palgrave.fsm.4760020

[21] Ladhari, R., Souiden, N. and Ladhari, I. (2011) Determinants of Loyalty and Recommendation: The Role of Perceived Service Quality, Emotional Satisfaction and Image. Journal of Financial Services Marketing, 16, 111-124. https://doi.org/10.1057/fsm.2011.10

[22] Lam, S.Y., Shankar, V., Erramilli, M.K. and Murthy, B. (2004) Customer Value, Satisfaction, Loyalty and Switching Costs: An Illustration from a Business-to-Business Service Context. Journal of Academy of Mark Science, 32, 293-311. https://doi.org/10.1177/0092070304263330

[23] Tam, J.L.M. (2004) Customer Satisfaction, Service Quality \& Perceived Value: An Integrative Model. Journal of Marketing Management, 20, 897-899. https://doi.org/10.1362/0267257041838719

[24] Churchill, G.A. and Surprenant, C. (1982) An Investigation into the Determinants of Customer Satisfaction. Journal of Marketing Research, 19, 491-504. https://doi.org/10.1177/002224378201900410

[25] Eggert, A. and Ulaga, W. (2002) Customer Perceived Value: A Substitute for Satisfaction in Business Markets. Journal of Business \& Industrial Marketing, 17, 107-118. https://doi.org/10.1108/08858620210419754

[26] Patterson, P. and Spreng, R. (1997) Modelling the Relationship between Perceived Value, Satisfaction \& Repurchase Intention in a Business-to-Business, Service Context: An Empirical Examination. International Journal of Service Industry Management, 8, 414-434. https://doi.org/10.1108/09564239710189835

[27] Woodruff, R.B. (1997) Customer Value: The Next Source for Competitive Advantage. Journal of the Academy of Marketing Science, 25, 139-153. https://doi.org/10.1007/BF02894350

[28] Roig, J.C.F., Garc1'a, J.S. and Tena, M.A. (2009) Perceived Value \& Customer Loyalty in Financial Services. The Service Industries Journal, 29, 775-789. https://doi.org/10.1080/02642060902749286

[29] Berkman, H.W., Lindquist, J.D. and Sirgy, M.J. (1997) Consumer Behavior. NTC Publishing Group, Lincolnwood.

[30] Oliver, R. (1999) Whence Consumer Loyalty? Journal of Marketing, 63, 33-45. https://doi.org/10.2307/1252099

[31] Andreassen, T.W. and Lindestad, B. (1998) Customer Loyalty \& Complex Services: The Impact of Corporate Image on Quality, Customer Satisfaction \& Loyalty for Customers with Varying Degrees of Service Expertise. International Journal of Services \& Industrial Management, 9, 7-23. 
https://doi.org/10.1108/09564239810199923

[32] Brakus, J.J., Schmitt, B.H. and Zarantonello, L. (2009) Brand Experience: What Is It? How Is It Measured? Does It Affect Loyalty? Journal of Marketing, 73, 52-68. https://doi.org/10.1509/jmkg.73.3.052

[33] Zeithaml, V.A., Berry, L.L. and Parasuraman, A. (1996) The Behavioral Consequences of Service Quality. Journal of Marketing, 60, 31-46. https://doi.org/10.2307/1251929

[34] Anderson, J.C. and Gerbing, D.W. (1988) Structural Equation Modeling in Practice: A Review and Recommended Two-Step Approach. Psychological Bulletin, 103, 411. https://doi.org/10.1037/0033-2909.103.3.411

[35] Hair, J.F., Black, W.C., Babin, B.J., Anderson, R.E. and Tatham, R.L. (2006) Multivariate Data Analysis (Vol. 6).

[36] Hair, J.F., Black, W.C., Babin, B.J. and Anderson, R.E. (2010) Multivariate Data Analysis. Pearson Prentice Hall, Upper Saddle River.

[37] Fornell, C. and Larcker, D.F. (1981) Evaluating Structural Equation Models with Unobservable Variables and Measurement Error. Journal of Marketing Research, 18, 39-50. https://doi.org/10.1177/002224378101800104

[38] Bagozzi, R.P. and Yi, Y. (1988) On the Evaluation of Structural Equation Models. Journal of the Academy of Marketing Science, 16, 74-94.

https://doi.org/10.1007/BF02723327

[39] Holbrook, M.B. and Corfman, K.P. (1985) Quality \& Value in the Consumption Experience: Phaedrus Rides Again. In: Jacoby, J. and Olson, J.C., Eds., Perceived Quality: How Consumers View Stores \& Merchandise, Lexington Books, Lexington, 31-57.

[40] Oliver, R.L. (1997) Satisfaction: A Behavioral Perspective on the Consumer. McGraw-Hill, Boston. 


\section{Appendix 1. Rotated Factor Matrix for Value Dimensions in Retail Banking}

\begin{tabular}{|c|c|c|c|c|c|}
\hline Factors & Measurement Items (Value Dimensions) & $\lambda$ & Alpha & CR & Literature \\
\hline \multirow[t]{4}{*}{ Service quality } & My banking service provider is giving outstanding Quality. & 0.646 & 0.797 & 0.763 & Petrick, 2002 \\
\hline & The service is very reliable. & 0.653 & & & \\
\hline & My banking service provider is dependable. & 0.656 & & & \\
\hline & My banking service is consistent. & 0.729 & & & \\
\hline \multirow[t]{5}{*}{ Emotional response } & My bank makes me feel good. & 0.585 & 0.769 & 0.772 & Petrick, 2002 \\
\hline & My bank gives me pleasure. & 0.697 & & & \\
\hline & My bank gives me a sense of joy. & 0.708 & & & \\
\hline & My bank makes me feel delighted. & 0.693 & & & \\
\hline & My bank gives me happiness. & 0.832 & & & \\
\hline \multirow[t]{6}{*}{ Monetary price } & My bank transaction is a good buy. & 0.618 & 0.826 & 0.861 & Petrick, 2002 \\
\hline & My bank is worth the money. & 0.812 & & & \\
\hline & My bank fairly priced. & 0.819 & & & \\
\hline & My bank reasonably price. & 0.693 & & & \\
\hline & My bank is economical. & 0.765 & & & \\
\hline & My bank appears to be a good bargain. & 0.772 & & & \\
\hline \multirow[t]{5}{*}{ Behavioral price } & My bank is easy to buy. & 0.656 & 0.741 & 0.746 & Petrick, 2002 \\
\hline & My bank required little energy to purchase. & 0.685 & & & \\
\hline & My bank is easy to shop for. & 0.717 & & & \\
\hline & My bank required little effort to purchase. & 0.657 & & & \\
\hline & My bank is easily bought. & 0.615 & & & \\
\hline \multirow[t]{5}{*}{ Reputation } & My bank has good reputation. & 0.625 & 0.814 & 0.819 & Petrick, 2002 \\
\hline & My bank is well respected. & 0.778 & & & \\
\hline & My bank is well thought of. & 0.799 & & & \\
\hline & My bank has status. & 0.672 & & & \\
\hline & My bank is reputable. & 0.883 & & & \\
\hline \multirow{11}{*}{$\begin{array}{l}\text { Customer service } \\
\text { experience }\end{array}$} & This bank makes a strong impression on my visual sense or other senses. & 0.783 & 0.923 & 0.952 & Brakus et al., \\
\hline & I find this brand interesting in a sensory way. & 0.893 & & & 2009 \\
\hline & This brand does not appeal to my senses. & 0.844 & & & \\
\hline & This brand induces feelings and sentiments. & 0.872 & & & \\
\hline & I do not have strong emotions for this brand. & 0.883 & & & \\
\hline & This brand is an emotional brand. & 0.775 & & & \\
\hline & I engage in physical actions and behaviors when I use this brand. & 0.812 & & & \\
\hline & This brand results in bodily experiences. & 0.873 & & & \\
\hline & This brand is not action oriented. & 0.814 & & & \\
\hline & I engage in a lot of thinking when I encounter this brand. & 0.773 & & & \\
\hline & This brand does not make me think. & 0.685 & & & \\
\hline
\end{tabular}




\section{Continued}

This brand stimulates my curiosity and problem solving.

Customer loyalty I will tell good things regarding my bank.

I will recommend this bank to someone that asks for my advice.

I will encourage my family and friends to make use of this bank.
0.724

0.872

0.814

0.821

Zethaml et al.,

0.725

1996

0.822 